\title{
Seroprevalence of Toxoplasma gondii infection in cats from Curitiba, Paraná, Brazil
}

\author{
Soroprevalência de infecção anti-Toxoplasma gondii em gatos domésticos de Curitiba, Paraná, Brasil \\ Marúcia de Andrade Cruz ${ }^{1,2}$; Leila Sabrina Ullmann³; Patrícia Yukiko Montaño²; \\ Juliano Leônidas Hoffmann³; Helio Langoni³; Alexander Welker Biondo ${ }^{1,4 *}$
}

${ }^{1}$ Departamento de Medicina Veterinária, Universidade Federal do Paraná - UFPR

${ }^{2}$ Clínica Veterinária Mania de Gato, Curitiba

${ }^{3}$ Departamento de Higiene Veterinária e Saúde Publica, Faculdade de Medicina Veterinária e Zootecnia, Universidade Estadual Paulista - UNESP

${ }^{4}$ Visiting Professor, Department of Veterinary Pathobiology, University of Illinois, Urbana-Champaign - UIUC

Received January 17, 2011

Accepted February 9, 2011

\begin{abstract}
Toxoplasmosis is a worldwide zoonosis caused by the protozoa Toxoplasma gondii which infects all warm-blood vertebrates. This study aimed to assess the seroprevalence of anti-Toxoplasma gondii antibodies in a population of domestic cats seen at a major cat-only veterinary clinic in Curitiba, Paraná State, Southern Brazil. Serum samples were processed by indirect immunofluorescence assay (IIFA) for the detection of IgG. Antibody titers were found in $16.3 \%$ (46/282) of sera analyzed, with titers to T. gondii of 16 in eight cats, 64 in 23 cats, 256 in 14 cats and 1024 in one cat. Statistical differences were not found regarding the association with age, gender and different areas of the city $(p>0.05)$. No significant differences were found in any variable when comparing seropositivity with potential risk factors. The seroprevalence was relatively lower when compared to other Brazilian regions, probably due to the fact that the cats studied were owned, domiciled with restricted dietary habits based on processed foods, restricted access to the street and no prey access. In conclusion, low feline toxoplasmosis seroprevalence may be associated to owned cats due to adequate dietary care and restricted outdoor access, as well as low local environmental exposure.
\end{abstract}

Keywords: Toxoplasma gondii, cats, indirect imunofluorescent antibodies test.

\section{Resumo}

A toxoplasmose é uma zoonose de distribuição mundial, causada pelo protozoário Toxoplasma gondii que infecta os vertebrados de sangue quente. Este estudo objetiva estabelecer a prevalência de anticorpos anti-Toxoplasma gondii e o estudo de associação em uma população de gatos domésticos atendidos em uma clínica veterinária exclusiva de gatos localizada em Curitiba, estado do Paraná, Brasil. As amostras de soro foram obtidas e processadas pela reação de imunofluorescência indireta IgG. Títulos de anticorpos foram encontrados em 46/282 (16,3\%) das amostras analisadas, com título de 16 em oito gatos, 64 em 23, 256 em 14 e 1024 em um gato. Diferenças estatísticas não foram encontradas no estudo de associação entre idade, gênero e regiáo da cidade $(p>0,05)$. Nenhuma diferença significativa foi encontrada para qualquer variável, quando comparando a soropositividade com a ocorrência do possível fator de risco. A soroprevalência foi relativamente menor quando comparada a outras regióes brasileiras, provavelmente por serem gatos de proprietários, que tinham hábito domiciliado e alimentaçáo restrita baseada em alimentos industrializados, com acesso restrito a rua e sem acesso a caça. Em conclusão, a baixa soroprevalência de toxoplasmose felina pode estar relacionada a gatos com proprietários devido aos cuidados alimentares e acesso restrito à rua, e também pode estar associada à baixa exposição ambiental local.

Palavras-chave: Toxoplasma gondii, gatos, teste de imunofluorescência indireta.

\footnotetext{
*Corresponding author: Alexander Welker Biondo

Departamento de Medicina Veterinaria, Universidade Federal do Paraná - UFPR,

Rua dos Funcionários, 1540, Juvevê, CEP 80035-050, Curitiba - PR, Brazil;

e-mail: abiondo@illinois.edu
} 
Toxoplasmosis is a worldwide infectious disease caused by Toxoplasma gondii which is an intracellular obligatory protozoan capable of infecting any warm-blood animal including humans (DUBEY, 2004). This parasite can be occasionally transmitted by ingestion of oocysts excreted on feces of felids, reportedly known as definitive hosts, or more commonly by the ingestion of cysts that are located into the musculature of intermediate hosts (DUBEY, 2008).

In addition to their role on toxoplasmosis cycle, domestic cats (Felis catus) have been increasingly found as non-human inhabitants of homes, particularly apartments, in Brazilian urban areas (SERAFINI et al., 2008). Cats, originally owned in rural areas due to their predatory abilities in controlling rodents, are currently considered family members (DABRITZ; CONRAD, 2010) with close human contact of public health impact.

Cats kept indoors may not contribute to toxoplasmosis spreading; however, cats with outdoor access can both eliminate oocysts in the environment and become a source of infection for their owners (DUBEY, 2008). Outdoor human activities involving soil contact such as gardening and playing in sandboxes may increase people's exposure to ooccysts and infection (DABRITZ; CONRAD, 2010). Hence, exposed human populations need to be made fully aware of potential environmental contamination with $T$. gondii oocysts by cats.

The prevalence of toxoplasmosis reported in Brazil varies according to different regions, from $19.5 \%$ in Rio de Janeiro (GONÇALVES NETTO et al., 2003), to $27.8 \%$ and $23.6 \%$ in São Paulo (LUCAS et al., 1998, 1999). An overall prevalence of $19.4 \%$ was reported in a previous study performed with samples from three cities in the state of São Paulo and one in the state of Paraná (LANGONI et al., 2001). After an acute outbreak of human toxoplasmosis a high rate of infection was seen in cats, with 49/58 (84.4\%) positive cats investigated (DUBEY et al., 2004).

Although several prevalence studies have been conducted in Brazil, few have investigated the association with toxoplasmosis in cats in Brazil. The present study aimed to assess the prevalence of Toxoplasma gondii infection in owned cats seen at a major catonly veterinary clinic in Curitiba, Southern Brazil, and to test the association of results to potential risk factors for cat infection.

Cat serum samples in this study were obtained at the "Mania de Gato" Clinic, a major first cat-only veterinary clinic in Southern Brazil, with around 1,000 registered cats at the time of study. A random sample of 278 cats was estimated to be representative of total clinic population (PIMENTEL-GOMES, 2000). However, our study sample was limited to healthy, owned cats receiving veterinary care. The sample was not representative of the city of Curitiba, which had about 1,788,559 inhabitants at that time (IBGE, 2007), a 25:8:1 proportion of humans-dogs-cats according to a previously study of our group (CRUZ, 2007). The feline population was estimated at 71,520 cats at the time of the study.

The cats underwent routine clinical examination, and a questionnaire was applied to owners to collect information on animal age, gender, neutering status, domiciled or not, eating and hygiene habits and city area. Information on risk factors was also collected in the questionnaire and included type of housing (farmhouse, townhouse or apartment), kitchen access, meat consumption, raw or cooked meat consumption, milk and filtered water consumption, prey access, sanitary habits (litter box or yard) and outdoor access. A comparison of risk factors was performed with the use of a non-parametric test (chi-square test) applied to a two-by-two table of positive and negative cats (PIMENTEL-GOMES, 2000). Serum samples were tested by immunofluorescent antibody test (IFAT) using titer 16 as a cutoff and considering positive a reaction with $\geq 50$ of fluorescent tachyzoites with conjugate anti-feline antibodies, as previously established (CAMARGO, 1974). The present study was approved by the Research Ethics Committee for Animal Use of Universidade Federal do Paraná (protocol number 005/2006).

Of 282 samples tested, $46(16.3 \%)$ were positive by IFAT for antibodies to $T$. gondii. The population studied comprised 144 females and 138 males; 27 females and 19 males were positive. Among the positive samples, the titer 64 was the most frequently seen $(23 / 46 ; 50 \%)$, and only one young cat had a titer 1024 consistent with acute infection (Table 1). According to age, $78 / 282(27.7 \%)$ were young (up to 1 year old), 181/282 (64.2\%) adults ( 1 to 8 years old) and 23/282 (8.1\%) were old ( $\geq 9$ years old); out of the seropositive cats, $11 / 78$ (14.1\%) were young, 29/181 (16.0\%) adult and 6/23 (26.1\%) old.

Although no statistical differences were found between negative and positive cats regarding gender and age $(\mathrm{p}>0.05)$, older cats tended to have higher rates of toxoplasmosis seropositivity. No significant differences between groups were found regarding risk factors, probably due to the fact that they were mostly owned cats with appropriate eating habits. Most cats consumed processed food and had little access to prey or any other kind of raw meat or milk products. In addition, most owners reported daily cleaning of litter boxes, reducing the risk of infection with sporulated T. gondii oocysts. Although most cats used to drink unfiltered tap water, no water contamination with $T$. gondii oocysts has ever been reported in Curitiba. The very particular characteristics of the cat population studied, sampled from a single major cat-only clinic and with responsible guardianship of owners, may explain the low prevalence of toxoplasmosis infection found in the present study. However, further studies are needed with other cat populations in the same metropolitan area of Curitiba to fully assess risk factors associated with $T$. gondii infection in cats.

To the authors' best knowledge, the prevalence (16.3\%) of anti- $T$. gondii antibodies found in the present study was the lowest reported in Brazil to date, probably due to the specific characteristics of the population studied, when compared to $19.5 \%$ reported in Rio de Janeiro, 27.8\% and 23.6\% in São Paulo and the overall prevalence of $19.4 \%$ in the states of São Paulo and Paraná (LUCAS et al., 1998, 1999; LANGONI et al., 2001; GONÇALVES NETTO et al., 2003). Moreover, the prevalence of toxoplasmosis infection found was not statistically different from a previous study conducted in Curitiba with stray cats, where a total of $25 / 145(17.2 \%)$ cats were found positive using the same methodology and laboratory testing (CRUZ, 2007). The authors believe that environmental contamination of cats in Curitiba is very low, but further studies are needed to fully know the toxoplasmosis cycle in this area.

No differences were found among the risk factors studied, probably due to the fact that cat feeding was not based on pork, pre-frozen meat and pasteurized milk. Despite the low prevalence 
Table 1. Serological results of IFAT from 282 cat samples tested to IgG anti-T. gondii, according to age, Curitiba/PR, 2007.

\begin{tabular}{lrrrrrrr}
\hline \multicolumn{1}{c}{ Age } & Number & \multicolumn{6}{c}{ Titers } \\
\cline { 2 - 8 } & & $\mathbf{1 6}$ & $\mathbf{6 4}$ & $\mathbf{2 5 6}$ & $\mathbf{1 0 2 4}$ & Negative & Positive \\
\hline Young & 78 & 03 & 04 & 03 & 01 & 67 & 11 \\
Adult & 181 & 03 & 15 & 11 & - & 152 & 29 \\
Old & 23 & 02 & 04 & - & - & 17 & 06 \\
Total & 282 & 08 & 23 & 14 & 01 & 236 & 46 \\
\hline
\end{tabular}

of toxoplasmosis infection found in the present study, veterinarians of Curitiba and surrounding areas should continuously educate pet owners on the important role cats play in the spread of toxoplasmosis and the importance of daily cleaning litter boxes and keeping their cats indoors. We hypothesize that neutering and non-spraying of cat population may have also contributed to a relatively lower level of environmental $T$. gondii oocyst contamination and therefore a relatively lower prevalence of infection in cats in Curitiba when compared to other regions of Brazil.

In conclusion, Curitiba showed a relatively low feline toxoplasmosis seroprevalence, which may be due to the sample studied of owned cats with adequate eating habits and restricted outdoor access, but also may be associated to low local environmental exposure.

\section{References}

CAMARGO, M. E. Introdução às técnicas de imunofluorescência. Revista Brasileira de Patologia Clínica, v. 10, n.3, p. 87-107, 1974.

CRUZ, M.A. Soroprevalência anti-Toxoplasma gondii (Nicolle \& Manceaux, 1908) em gatos domésticos (Felis catus-Linnaeus, 1758) de Curitiba, Paraná. 2007. 77f. Dissertação (Mestrado em Patologia Veterinária)-Universidade Federal do Paraná, Curitiba.

DABRITZ, H.A.; CONRAD, P.A. Cats and Toxoplasma: implications for public health. Zoonoses and Public Health, v. 57, n.1, p. 34-52, 2010. PMid:19744306. http://dx.doi.org/10.1111/j.1863-2378.2009.01273.x
DUBEY, J.P. Toxoplasmosis - a waterbone zoonosis. Veterinary Parasitology, v. 126, n.1-2, p. 57-72, 2004. PMid:15567579. http://dx.doi.org/10.1016/j.vetpar.2004.09.005

DUBEY, J.P. The history of Toxoplasma gondii: the first 100 years. Journal of Eukaryotic Microbiology, v. 55, n. 6, p. 467-475, 2008. PMid:19120791. http://dx.doi.org/10.1111/j.1550-7408.2008.00345.x

DUBEY, J.P. et al. Toxoplasma gondii infections in cats from Paraná, Brazil: seroprevalence, tissue distribution, and biologic and genetic characterization of isolates. The Journal of Parasitology, v. 90, n. 4, p. 721-726, 2004. PMid:15359466. http://dx.doi.org/10.1645/GE$382 \mathrm{R}$

GONÇALVES NETTO, E. et al. Ocorrência de gatos soropositivos para Toxoplasma gondii Nicolle e Manceux, 1909 (Apicomplexa: Toxoplasmatinae) na cidade de Niterói, Rio de Janeiro. Revista Brasileira de Parasitologia Veterinária, v. 12, n.4, p. 145-149, 2003.

INSTITUTO BRASILEIRO DE GEOGRAFIA E ESTATÍSTICA -IBGE. Curitiba. Rio de Janeiro, 2007. Disponível em: <www.ibge.gov. br>. Acesso em: 20 jun. 2007.

LANGONI, H. et al. Prevalência de toxoplasmose em gatos dos Estados de São Paulo e Paraná. Brazilian Journal of Veterinary Research and Animal Science, v. 38, n.5, p. 243-244, 2001.

LUCAS, S.R.R. et al. Ocorrência de anticorpos antitoxoplasma em gatos infectados naturalmente pelo vírus da imunodeficiência dos felinos. Brazilian Journal of Veterinary Research and Animal Science, v. 35, n. 1, p. 41-45, 1998. http://dx.doi.org/10.1590/S003646651999000400003

LUCAS, S.R.R. et al. Toxoplasma gondii Infection in Brazilian Domestic Outpatient Cats.Revista do Instituto de Medicina Tropical de São Paulo, v. 41, n.4, p. 221-224, 1999.

PIMENTEL-GOMES, F. Curso de Estatística Experimental. 14. ed. Piracicaba: Universidade de São Paulo, Escola Superior de Agricultura Luiz de Queiroz, 2000. p. 301-312.

SERAFINI, C.A. et al. Survey of owned feline and canine populations in apartments from a neighbourhood in Curitiba, Brazil.Zoonoses Public Health,v.55, n.8-10, p.402-405, 2008. PMid:18811904. http://dx.doi. org/10.1111/j.1863-2378.2008.01171.x 